バイオイメージング特集III：ディジタル画像処理（ナノマシン集合体レベル）

電子線トモグラフィー

峰雪 芳宣 ${ }^{1}$ 須田 甚将 ${ }^{2}$ 、唐原 一郎 ${ }^{2}$

${ }^{1}$ 広島大学大学院理学研究科生物科学専攻（干739-8526 東広島市鏡山1-3-1）、

2 富山大学理学部生物学科（广930-8555 富山市五福3190）

\title{
Electron tomography
}

\section{Yoshinobu Mineyuki ${ }^{1}$, Jinsuke Suda ${ }^{2}$, Ichiro Karahara ${ }^{2}$}

\begin{abstract}
${ }^{1}$ Department of Biological Science, Graduate School of Science, Hiroshima University, Higashi-Hiroshima, 739-8526, Japan,

${ }^{2}$ Department of Biology, Faculty of Science, Toyama University, Toyama, 930-8555, Japan
\end{abstract}

要旨 : 生命現象を実際に司っているナノマシンあるいはより高次な集合体で構成されるナノシステム が、いつ、どこで、どの様な挙動をしているか、直接見ることは生命現象の解析には必要不可欠であ る。これら、ナノレベルの観察には電子顕微鏡が必要であるが、最近まで、固定と画像処理技術の問 題で解析に限界があった。最近になって、試料の凍結技法の進歩と電子線トモグラフィーによる $3 \mathrm{D}$ 解析法の開発により、従来よりも信頼のできるナノレベルでの細胞内構造の解析が可能になつた。本 稿では、ナノレベルでのバイオイメージング技術の例として、電子線トモグラフィー技術の歴史と方 法について概説する。

Summary : To determine how, where and when nano-machines and/or nano-systems act within cells is necessary for understanding life phenomena. To analyze the cellular structure at nano level, electron microscope is necessary. However, until recently, the analysis of cellular structure by electron microscopy has been limited by both specimen preparation method and by image analysis problems. Both of these limitations can be overcome by combining cryofixation methods in conjunction with electron tomography. In this lecture, we will describe the history and the method of electron tomography.

Key words : electron tomography; high pressure freezing; cytoskeleton; onion; high voltage electron microscopy. 


\section{1.はじめに}

生命現象の多くは、個々の生体分子の単独プレーではなく、何種類かの生体分子が集まった高分子 集合体として一つのナノマシンを形成し機能することが多い。分子生物学的手法で、バイオナノマシ ンの個々の構成分子が次々と明らかになり、その分子構造はX線結晶解析等の構造生物学的手法で（凡 レベル）、た、分子の細胞内での挙動は蛍光プローブと蛍光顕微鏡を使った生体内でのライブイメ ージングで（ $\mu \mathrm{m}$ レベル）解析できるようになって来ている。しかし、実際の生命現象は様々なナ～ マシンが集まった、より高次の集合体の場（ナノシステム）を形成して行われる。そのため、これら ナノマシンがどのように相互作用して一つの生命現象を引き起こしているか、その現場の生の様子を 見る必要がある。つまり、ナノレベルでのバイオイメージングが必要である。この目的に要求される のは分解能1〜10nmの世界である。このスケールで観察する装置は電子顕微鏡であるが、従来の電 子顕微鏡法では、固定法と画像解析法に限界があり、真実に近い形でナノスケールでの 3 次元定量解 析がなかなか進まなかった。最近になり、試料の凍結技法の進歩と、コンピューター技術の進歩で高 容量の情報を高速で扱える様になり、凍結した試料を使った電子線トモグラフィーの技術が、新しい 技術として注目を集めている。本稿では、コンピュータートモグラフィーの説明から始めて、現在の トモグラフィー技術の使われ方、電子顕微鏡での応用の仕方について説明し、最後に実際我々がやっ ている加圧凍結・2 軸電子線トモグラフィー法の説明とそれで得られた結果について紹介する。

\section{2.コンピュータートモグラフィー（CT）とは?}

CT検査とか断層写真という言葉は、病院で良く聞く言葉である。このCTがコンピュータートモグ ラフィーのことで、外科的な手術をしなくても体の中の断面が見えるので、癌の早期発見などに役立 つている技術である。CTとは、X線等を使って多方向から投影した画像を元に、コンピューターで 数学的な処理をすることにより真の断面像を再生する技術である。この手法を電子顕微鏡に応用した のが電子線トモグラフィー (electron tomography) である。

\section{3. СTの歴史}

19 世紀末のRentogenによるX線の発見以降、人類は体の中を透かしてみる技術を手に入れるこ とになった。しかし、X線写真は 3 次元の立体構造を 2 次元に投影した像であり、奥行きの情報が失 われてしまう。それを補うための断層写真法が古くから工夫されてきたが、周りのぼけを取り除くの が難しく、コントラストが低下し満足のいく画像は得られなかった。1973年に英国のEMI社の技術 者HounsfieldがX線CTを開発（Hounsfield 1973）し、従来のものとは比べ物にならないくらい良 い画像が得られるようになり、この技術が特に医療分野で広がった。この方法と同じ様な原理は、そ れよりも前にCormack（1963）がガンマ線を使って発表していたため、1979年にHounsfieldと Cormackの 2 人がCTの業績でノーベル医学・生理学賞を受賞した。

確かに実用性と一般へのインパクトの大きさから医療分野のCTが注目されて来たが、CTの数学的 理論は1917年にRadonによって提唱されており（Radon 1917）、Hounsfield以前にも、電子顕微 鏡、電波天文学、光学などの分野で研究されていた様である。ただ、コンピューター技術の進歩にう まく乗り、実用化にこぎ着けたHounsfieldのX線CTの発表が、デジタル画像処理が本格的に実用化 されるきっかけとなったことは確かである。その後、コンピューターの処理能力とメモリー容量が飛 躍的に発達することにより、より高速、高画質のデータが得られる様になって来た。植物科学分野で 
も、電子線トモグラフィー以外に、X線CTによる器官の 3 次元観察 (Stuppy et al. 2003) やNMR 顕微鏡による植物体内の水の移動の観察（Köckenberger 2001）等にもCTが使われている。

\section{CTの原理}

Radonの考えたCTの数学的原理を説明した のが図1A,Bである。図1A中央にある白黒の 模様が見たい断面の真の姿だとする。これは 2 次元の様々な点の集まりと考えられる。こ こでは $\mathrm{x}, \mathrm{y}$ 座標上の個々の吸収係数を持った 点の集まりとして、この点の吸収係数を $\mathrm{f}(\mathrm{x}$, y)と表すことにする。この像に 1 方向から平 行なビーム（例えばX線）を当てると、各点 の吸収係数に従ってビームの強度が減少し、 1 次元の濃淡パターンの情報が検出できる。 これを投影図と呼ぶ。投影図の個々の点（投 影データ）は、ビームが通過して来た直線上 の吸収係数の值の総和に比例する。（x, y) 座標系から角度 $\theta$ だけ回転させた座標系を（r, S）とすると、角度 $\theta$ の方向から投影したビー ムの投影データ（ここでは、 $\mathrm{p}(\mathrm{r}, \theta)$ と表す）は、
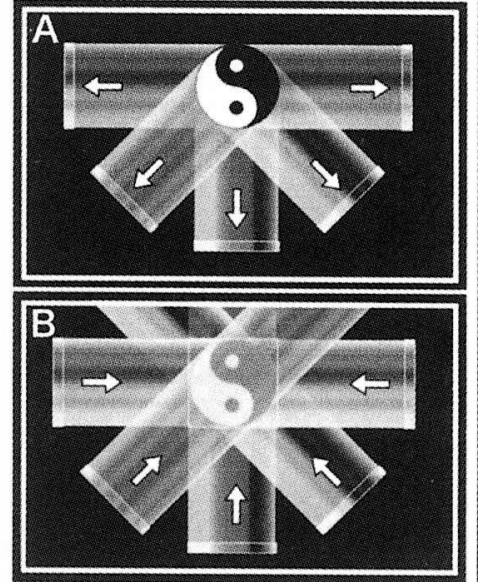

C Get serial images

Rough alignment

Refined alignment

(using gold particles)

Caliculate tomogram

Serial images of

1 pixel thickness

Movie Model

図 1.コンピュータトモグラフィー (CT) 法の原理 (逆投影法)。A：2 次元から 1 次元への投影。異 なる角度からオブジエクトの 1 次元の投影図を得 る。B : 1 次元から 2 次元への逆投影。A で得られ た投影図を元に演算によって 2 次元の再構築を行 う。C : 実際の画像再構築の流れ。

像中、数式で $\mathrm{x} \cos \theta+\mathrm{y} \sin \theta=\mathrm{r}$ と表現でき

る直線上にある点の值の総和となる。つまり、 $\mathrm{p}(\mathrm{r}, \theta)$ はビームが通過した直線上の線積分を意味する。 この変換は $\mathrm{f}(\mathrm{x}, \mathrm{y})$ に $\mathrm{p}(\mathrm{r}, \theta)$ を対応づける積分変換と考えられ、発見者にちなんで Radon変換と呼ば

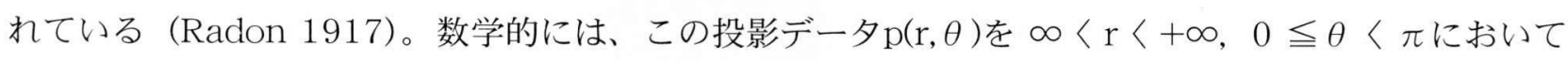
計算し逆変換すれば原画像の各点の $\mathrm{f}(\mathrm{x}, \mathrm{y})$ が得られるはずである。つまり、様々な角度から投影 (projection ; 図1A）し、それを逆投影（backprojection；図1B）して重祮合わせることにより、元の画像が再構 成できるというのが、CTの基本原理である。

互いに $180^{\circ}$ 異なる力向からの投影データ（図 $1 \mathrm{~A}$ 右側から横に進行したビームの投影データと 左側から横方向に進行したビームでの投影データ）は全く同じ情報になるので片方だけで十分で、実 際には $360^{\circ}$ すべての方向から撮る必要はなく、半分の $180^{\circ}$ の範囲の情報を得れば良い。ビームも X線である必要はなく、上記のRadon変換の条件を満たすものであれば良い。また、現実には、 Radonの方法はあまり実用的でなく、再構成のプログラムはこの 30 年間にいろいろ開発され、幾つ かのアルゴリズムが使用されている。代表的なアルゴリズムにFilter Back Projection法がある。こ の方法は以下の 3 つの手順（数式処理）で行われる。数学的な詳細はKak and Slaney (1988）、 馬場（2004）の総説を参照されたい。

（1）投影データの 1 次元フーリエ変換

(2) フィルターリング

(3) 逆投影 
（2）のフィルタリングとは、（1）のフーリエ変換したものに、高域強調フィルター（空間周波数 の絶対値に比例したフィルター関数）を掛け、その後に 1 次元フーリエ逆変換を行う操作である。（1）、

（2）の操作の代わりに、畳み込み積分（convolution integral）を行っても同様の効果がある。こ の方法をConvolution Back Projection法と呼ぶ。その他の再構成法としては、反復再構成法 (Iterative Reconstruction Technique) 、SIRT (Simultanious Iterative Reconstruction Technique) 、 ILST (Iterative Least-Squares' Technique) 等の方法がある（馬場 2004）。

\section{5. 電子線トモグラフィー法}

電子顕微鏡でトモグラフィーを行うためには、 Radon変換の条件を満たすこと、つまり“透 過度の強度の減少が電子線の入射方向への投影 試料密度に比例する”ことが前提条件になる。 材料系の試料などでそのままではこれを満たさ ない場合は、別の工夫が必要である（田中 2004）。 トモグラフィーでは、様々な角度から投影した 画像を得る必要がある。電子顕微鏡の場合、試 料ステージの構造等の問題から、試料の回転に 限界がある。試料を支える金属部分があるため、 電子線と平行になるまで試料を傾ける（試料を $90^{\circ}$ 傾ける）と、メッシュの金属部分あるいは、 それを支持する部分によって電子線が試料に届 かなくなる。そこで、実際には+60 から-60 まで、120の範囲しかとれないことになる。
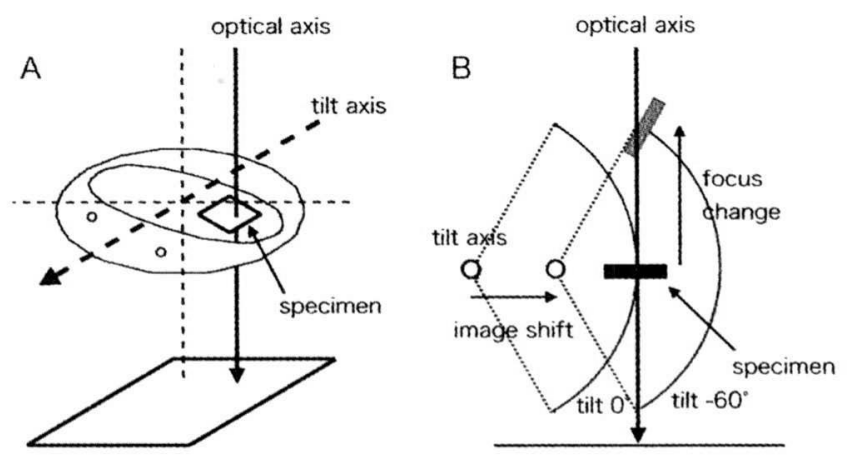

図 2. 傾斜切片画像の取得方法の模式図。+60 〜 - $60^{\circ}$ まで 1 または $1.5^{\circ}$ 刻みで傾斜切片画像を 取得する。 A : tilt 0 ○におけるグリッドの状態。 B : 傾斜に伴った傾斜軸と試料の移動。黒 : tilt 0 。に おりる傾斜軸、灰: tilt $-60^{\circ}$ における傾斜軸。傾 斜軸の移動に伴つて焦点と画像の移動が行われる。 試料の見たい場所が必ずしも回転軸上にあると は限らないので、傾けて、同じ場所に焦点を合わせながら撮影して行くのは結構大変で、具体的な 方法は図 2 に示している。残りの60 は、情報欠落領域 (missing data-range) と呼ばれ、この領 域が大きいほど像が悪くなる。最近では試料ステージを工夫して $80^{\circ}$ まで傾けた例もある。

電子顕微鏡で実際に使える 3 次元の画像化は、英国MRC研究所のKlugのグループがネガティブ染 色したT4ファージ鞭毛の螺旋構造を再構成したのが最初である（DeRosier and Klug 1968）。生 体高分子のトモグラフィーはHoppeら（1974）が脂肪酸合成酵素の再構築に成功したのが最初であ る。その後、ウイルスや高分子複合体などの電子顕微鏡による立体構造の解析では、試料を含む水 溶液をメッシュに載せ、そのまま極低温に冷やしたプロパンかエタンの溶液に浸漬して凍らせる氷 包埋の技術と、極低温下で試料を直接観察できるクライオ電子顕微鏡 (cryo-electron microscopy) の発達とともに進歩して来た。電子線トモグラフィーでは、たくさんの画像をとらなければならな いこと、観察できるだけの強さの電子線量を確保することという相反する条件がある。単離した生 体高分子の場合、水包埋した試料上には同じ分子がランダムな方向に配向しているため、一度にた くさんの方向を向いた画像を得られるので、この様々な方向を向いた画像を利用してトモグラムを 作製する単粒子解析法 (single-particle analysis) という技術が使われている (van Heel et al. 2000, 佐藤ら 2002)。一方、クライオ電子顕微鏡を使ってトモグラフィーを作製するクライオ電子 線トモグラフィー (cryo-electron tomography) の細胞への応用は、電子線を透すことの可能な扁 
平な単細胞で成功している。Madeliaら（2002）は、粘菌の細胞をメッシュ上で培養し、そのまま 凍結、クライオ電子線トモグラフィー法で立体再構成して細胞内構造を観察し、細胞内のアクチン ネットワークや26Sプロテアソームを検出した。

\section{6. 加圧凍結・2 軸電子線トモグラフィー法}

凍結電子線トモグラフィー法は、試料をそのま ま凍結するため、生に近い状態で見える特徵があ る。しかし、クライオ電子顕微鏡で観察している 間の観察ビームによる損傷の問題から、観察時間 に制限がある。また、試料の凍結できる厚さに限 界がある。例えば筆者らの研究の目的の一つ"気 孔分化過程での細胞分裂パターンの制御機構の解 明"では、トモグラフィー法で観察したい場所は たくさんの細胞の並びの中の特定の細胞の、ある 限られた部分（例えば、孔辺母細胞の分化のため の不等分裂の分裂面予定位置など）になる。そう すると、電子顕微鏡下でその場所を探し当てるの に時間がかかり、観察前に電子線で試料が損傷し

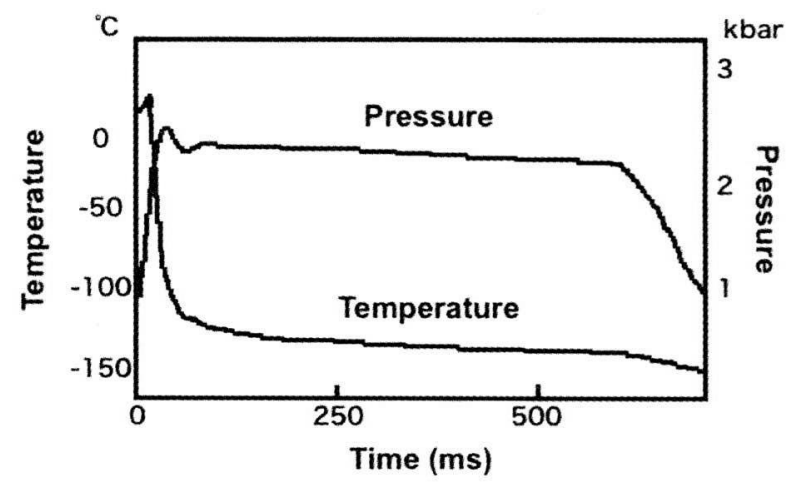

図 3.BAL-TEC HPM010を用いた加圧凍結の 際の温度および圧力の時間変化。HPF開始後約 10 ミリ秒で試料表面は- $50^{\circ} \mathrm{C}$ まで冷却される。 約 0.5 秒間以上 $2.1 \mathrm{kbar}$ 以上に圧力が保たれ る。

てしまう恐れがある。また、急速凍結法ではうま

く凍結できるのは表面の限られた領域であり、厚い試料には適応できない。そこで、これらの問題 を解決して行われているのが、加圧（高圧）凍結法で試料を凍結し、凍結置換後樹脂に包埋、切片 にしてトモグラフィーを行う方法で、コロラド大学のグループが中心に開発してきた (http://bio3d.colorado.edu/)。コロラド大学のトモグラフィー法の全体的な内容はMcIntosh（2001） が述べているので、以下は我々がコロラド大学との共同研究で行っている植物材料における加圧凍結・ 2 軸電子線トモグラフィー法について説明する。

凍結法 従来の急速凍結法では、せいぜい表面か ら数十 $\mu \mathrm{m}$ までしかうまく凍結できない。加圧凍 結法は $2.1 \mathrm{kbar}$ 以上の圧力下では氷の状態が変化

図 4. 加圧凍結法 (HPF) と圧着法（Metal contact) によるタマネギ子葉表皮細胞の凍結状 態の違い。A：加圧凍結法で凍結した細胞。Aの 両脇のバーは細胞表面からの深さによる凍結状 態を示し、黒は良い凍結状態の領域、白は氷晶形 成により組織の破壊が起きている領域をさす。加 圧凍結法では細胞 1 層の深さは十分保存される が、圧着法では細胞の表層しか保存されない。 bar=10 $\mu \mathrm{m}$ 。B：良く保存されたゴルジ体（加 圧凍結法)。A 中矢印の拡大図。 $\mathrm{bar}=0.5 \mu \mathrm{m}$ 。 C : 氷晶形成により破壊されたゴルジ体（圧着法）。

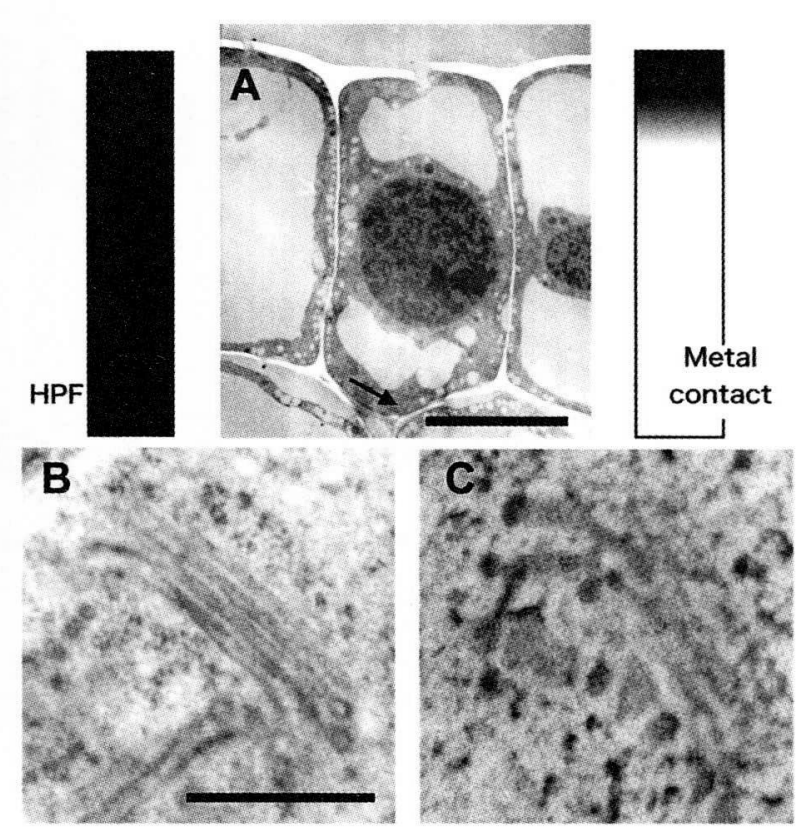


し、承の結晶の成長が遅くなることを利用した凍結で、この方法だと数百 $\mu \mathrm{m}$ まで凍結可能と言われ ている（村田ら 2000）。実際にBAL-TEC社の加圧凍結装置HPM010で加圧凍結した試料の凍結過程 での温度と圧力の変化をモニターしたのが図 3 である。圧力の上昇と温度低下の微妙なバランスの上 になりたっている装置で、約 20 ミリ秒以内に凍結できれば、だいたいの試料で $200 \mu \mathrm{m} の$ 厚さまでは うまく凍結できる (峰雪ら 1998図参照)。図 4 は我々の材料で、加圧凍結法と液体へリウム温度まで
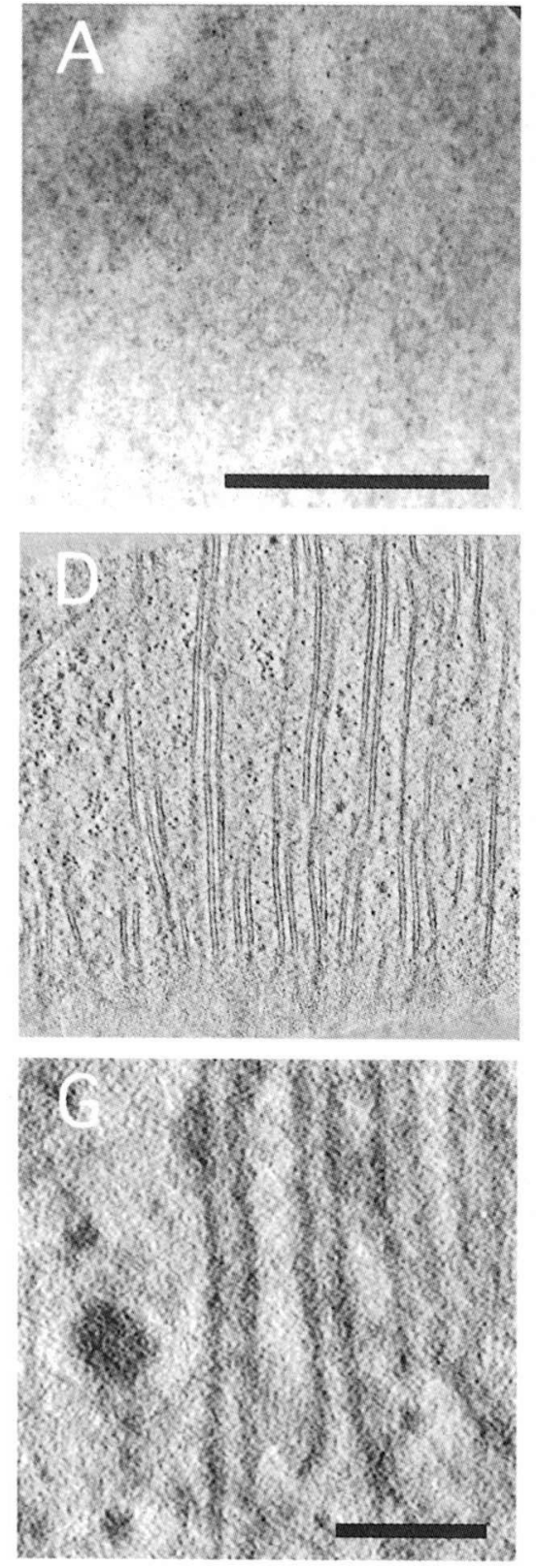
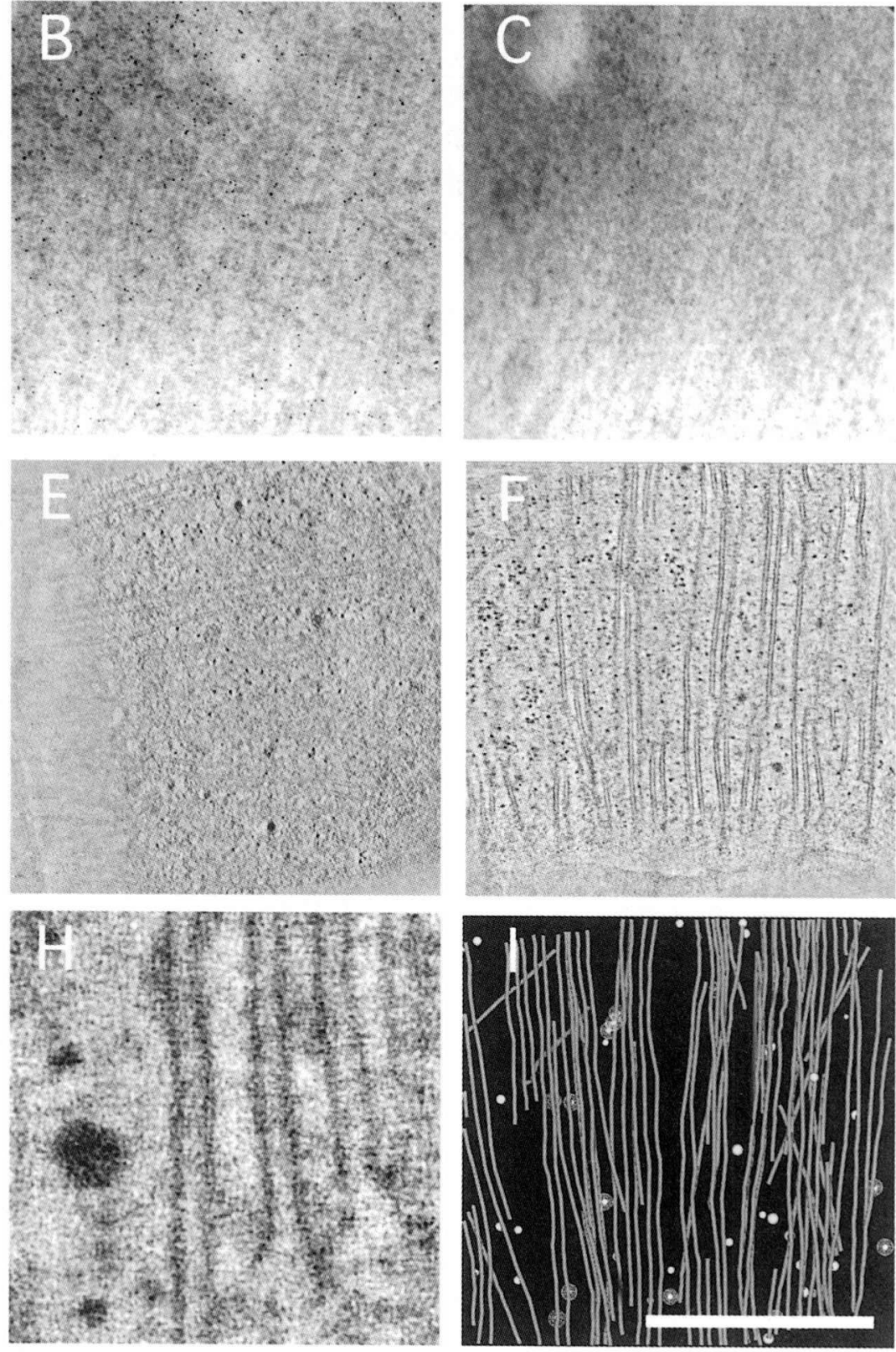

図 5 .夕マネギ表皮細胞における分裂準備帯の 3 次元構築過程。 $\mathrm{A} \sim \mathrm{C}$ : 異なる傾斜角での傾斜切片画像。 $\mathrm{A}, \mathrm{B}, \mathrm{C}$ はそれぞれ順に傾斜角 $+60^{\circ}, 0^{\circ},-60^{\circ}$ での画像を示す。D:連続傾斜切片を元に演算によって得 られた 1 軸トモグラム中のトモグラフィックスライス。 $\mathrm{E}: \mathrm{D}$ を得た傾斜軸を $90^{\circ}$ 回転した連続傾斜切片 から得た 1 軸トモグラム中のトモグラフィックスライス。この場合、試料の傾斜軸が微小管の方向に対し て垂直なため、微小管が鮮明に見えていない。F : D , Eのトモグラムを合同した 2 軸トモグラム中のトモ グラフィックスライス。 bar= $1 \mu \mathrm{m}$ 。 G , H : 1 軸トモグラムと 2 軸トモグラムの解像力の差を示す図。 $\mathrm{G}$ とHはそれぞれDとFの一部を拡大したもの。bar=80nm。I : 2 軸トモグラムの 3 次元モデルの 2 次 元への投影図。bar=1 $\mu \mathrm{m}$ 。 
冷却した金属に圧着して急速凍結した場合（圧着法）との比較をしたものであるが、加圧凍結だと 表皮細胞全体がうまく凍結できているのに対し、この急速凍結法だと、表面から $5 \mu \mathrm{m}$ 程度までしか うまく凍結できない。

試料作製 うまく凍結できても、凍結置換、樹脂包埋の過程で構造が破壊されてはどうしようもない。 そのため、凍結置換・樹脂包埋の方法が重要である。我々は試行錯誤の末、微小管だけでなくアク チン繊維も比較的安定に保存できる方法を確立した（Murata et al. 2002）。その方法は以下の手順 である。アセトンに溶かした $2 \% \mathrm{OsO} 4$ 中で、 $-80^{\circ} \mathrm{C}\left(2 \sim 3\right.$ 日) $\Rightarrow-20^{\circ} \mathrm{C}$ (1日) $\Rightarrow 4^{\circ} \mathrm{C}$ (一晚) $\Rightarrow$ 室温 (1時間) $\Rightarrow 40^{\circ} \mathrm{C}$ (4時間) $\Rightarrow 4^{\circ} \mathrm{C}$ アセトン溶液で洗浄 $\Rightarrow 4^{\circ} \mathrm{C}$ メ夕ノールに溶かした $5 \%$ 酢 酸ウラン ( 2 時間) $\Rightarrow$ 徐々にspurr樹脂に置換。各処理の詳細は峰雪ら（2001）に示している。

トモグラム作製の前段階として、樹脂に包埋した試料から $250 \mathrm{~nm}$ 厚の切片を作製し、フォルムバ 一ル膜を張ったスロットメッシュの中央に載せる。我々の試料では、すでに酢酸ウランでブロック 染色しているので、染色なしでもある程度観察可能である。そこで、できた試料は電子顕微鏡で予 備観察を行い、目的の場所を含む切片が載つているメッシュを選び、見たい場所を見つけ、その場 所の低倍の画像を記録しておく。選んだメッシュを酢酸ウランと鉛で 2 重染色し、コントラストを 高めた後、トモグラフィー用の位置合わせに使用する目的で、試料の載つたメッシュの両側に $10 \mathrm{~nm}$ あるいは $15 \mathrm{~nm}$ の金粒子をまぶせる。必要に応じて、あらかじめカーボンコートしてフォルムバール 膜を補強する。

画像取得試料作製後は、図1Cに示した手順に従って、（1）連続した画像の取得（図5A-C)、（2） 各画像の粗な位置合わせ、（3）金粒子を使つた精密な位置合わせ、（4）トモグラムの計算（図 5D-F)、（5）でき上がつたトモグラムのムービー表示、あるいは、トモグラムを元にモデルの作製 （図5I）を行う。我々は 2 種類の電子顕微鏡を使っている。1 台は、JEOLの超高圧電子顕微鏡（電

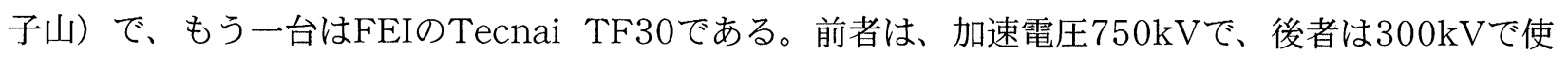
用している。画像の取得は、前者は画素数が $1 \mathrm{k} \mathrm{x} 1 \mathrm{k}$ CCDカメラを、後者は $2 \mathrm{k} \mathrm{x} 2 \mathrm{k}$ CCDカメラ を使用している。我々は微小管の端や小胞の形態の定量的解析を目標にしているため、目的の構造 が区別できる分解能とともに、できるだけ多くの数を視野に入れる必要がある。そこで、1kx $1 \mathrm{k} の$ カメラの場合は、隣り合う 4 枚、あるいは 6 枚をとつて重ね合わせた像を 1 枚の像として扱う様に している。Tecnai TF30では、カメラ自体が $2 \mathrm{k}$ x 2kなので、重ね合わせする必要がなく、しかも かなりの過程が自動化されており、ひとシリーズ 1 時間程度で撮影が終わる。以下、実際のプロセ スをTecnai TF30の場合で説明する。

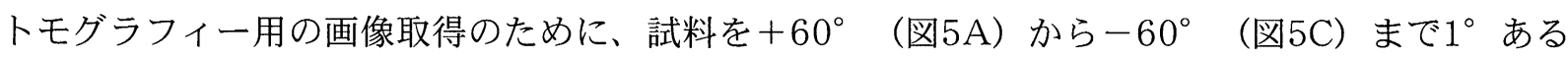
いは $1.5^{\circ}$ ステップで回転しながら連続画像を取得した後、試料を水平の位置（図5B）に戻し、水平 方向に 90 度回転し、再度 $+60^{\circ}$ から $-60^{\circ}$ まで別の軸で回転して 2 組の連続画像を取得する。

トモグラム作製と解析ソフト 取得した画像データーを別のコンピューターに転送し、まず、個々 の連続画像から、各々 1 軸の 3 次元画像（トモグラム）を作製（図 $5 \mathrm{D}, \mathrm{E}$ )、その後この二つのトモグ ラムを合わせることで最終的なトモグラム（図 $5 \mathrm{~F}$ ）を完成させる。2 組のデーターを結合させるこ とで、情報欠落領域を減らし分解能を上げることができる (図GとHを比較)。この方法を 2 軸電子 線トモグラフィー法という（Mastronarde 1997）。完成したトモグラムは、 $\mathrm{x}-\mathrm{y}$ 平面に切断した画 像（図5Fの様な画像）がZ軸方向に100枚以上重なった形で示し、これをトレースすることで、モデ ルを作製する（図 5I）。トモグラム作製およびそれ以降のモデル作製には、The Boulder Laboratory for 3-D Electron Microscopy of Cellsで開発されたソフトIMOD (Kremer 1996, 
Mastronarde 1997）を使用している。こ のプログラムは、画像取得の際に、試料の 傾斜角や位置が少々ずれても、金粒子はメ ッシュの上面と下面に存在しているはずだ から、その位置は、2 2 つ平面に分布する はずであるという仮定の下に、金粒子で位 置補正が可能である（図6)。また、コンピ ユーターを選べば、大容量の画像を扱える 特徵があり、Linux、MacOSX、Windows などで動作可能である。

\section{7.タマネギ表皮での結果}

実際に我々がタマネギ子葉表皮の分裂準 備帯（preprophase band）で作ったトモ グラムでは、 2,800 x 2,800 x 250 nmの 領域を $1.42 \mathrm{~nm} / \mathrm{pixel}$ で立体再構成でき、 1 個のトモグラムの中に39個の微小管の端 と124個の小胞を見つけることができた。こ の微小管端は、図7の様に、プロトフィラメ ントがシート状になって伸長していると思 えるもの（図7A、先端が平らなもの（図7B）、 プロトフィラメントが 1 本、1 本ほどけて、 コイル状に巻き、短縮していると思えるも の（図7C)、rチューブリンリング複合体で キャップされていると思われるもの（図7D） が見つかり、この方法で微小管のダイナミ ックスが推測できることが分かった。我々 のトモグラムの写真は、峰雪ら (2001)、 峰雪・唐原（2004）にも掲載している。

\section{8. 今後の展開}

従来の電子顕微鏡では難しかったナノレ ベルでの $3 \mathrm{D}$ 解析ができる電子線卜モグラフ イー法は、今後、バイオナノマシンやナノ システムの構造やダイナミックスの研究に 重要な技術である。この技術は、加圧凍結 法という、厚い組織でも凍結できる技術と 結びつくことにより、より真実に近い形で のナノレベルでの立体構造解析が可能になり、

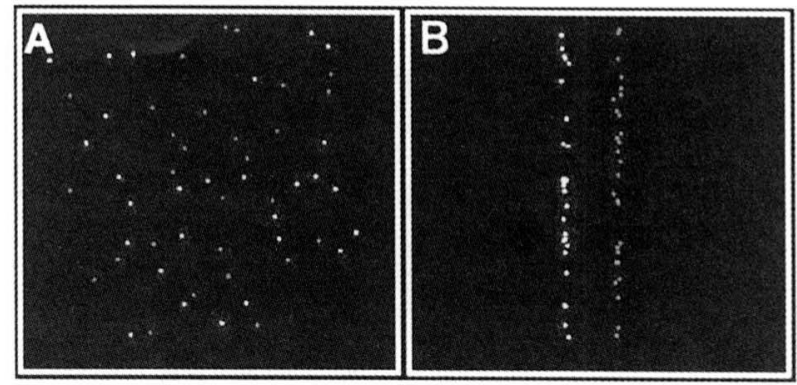

図6.試料表面に付着させた金粒子を用いた位置 合わせ。取得直後の傾斜切片画像は相対的な位置 が合っていないため、試料両表面上（白：表側、 灰：裏側）の金粒子を元に傾斜切片画像の位置合 わせを行う。図は位置合わせ後の金粒子分布の正 面図 (A)、と側方図 (B)。金粒子は 2 つの平面 に分布しているので、側方図（B）では金粒子は 2 つの直線上に並ぶ。
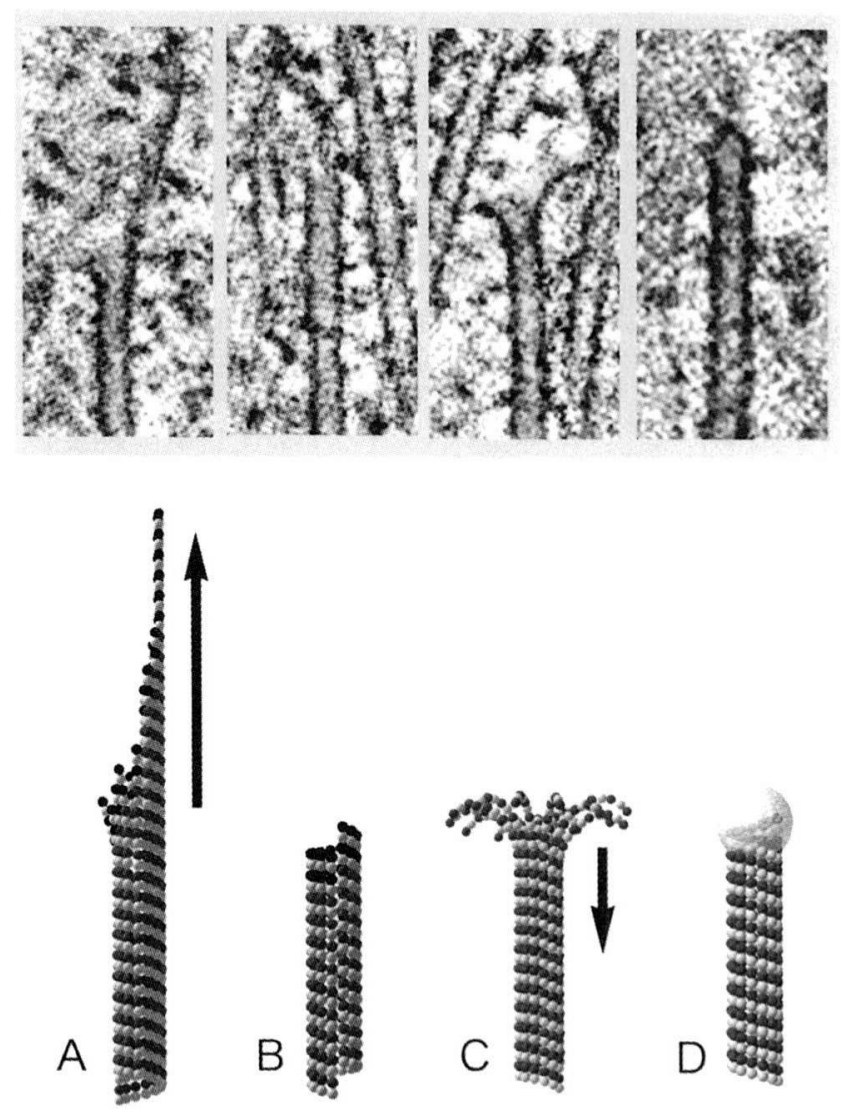

図 7 . タマネギ子葉表皮のトモグラムから得た 4 個の特徽的な微小管端の像（上段）と、それに対 応すると思われる微小管端モデル（下段）。下段 矢印は微小管の伸長、短縮の方向を示している。 A : Open sheet 型。伸長（重合）している時に 見られると考えられている。B：Blunt end 型。 $\mathrm{C}$ : Coiled end 型。脱重合時に見られると考えら れている。D : Capped end型。 $チ$ チュブリン・ リング複合体でキャップされたマイナス端の可 能性が大きい。 
今後の発展が期待できる。

\section{謝辞}

本総説の内容は、著者らがコロラド大学のAndrew L. Staehelin博士との共同研究で行った結果を 元にしている。Staehelin博士とその研究室のメンバー、及びコロラド大学Laboratory of 3D Electron Microscopy of Cellsのスタッフ諸氏に感謝いたします。本成果の一部は、科学研究費 (平成15、16年度萌芽研究No. 15657017) で行ったものである。

\section{文献}

馬場則男 (2004) 電子線トモグラフィー再構成の原理. 顕微鏡 39: 4-10.

Cormack, A. M. (1963). Representation of a function by its line integrals with some radiological applications. J. Appl. Phys. 34: 2722-2727.

DeRosier, D. J. and Klug, A. (1968). Reconstruction of three dimensional structures from electron micrographs. Nature 217: 130-134.

Hoppe, W., Gassmann, J., Hunsmann, N., Schramm, H. J. and Sturm, M. (1974). Three-dimensional reconstruction of individual negatively stained yeast fatty-acid synthetase molecules from tilt series in the electron microscope. Hoppe-Seyler's Z. Physiol. Chem. 355: 1483-1487.

Hounsfield, G. N. (1973). Computerized transverse axial scanning (Tomography), Part I. description of system. British J. Radiology 46: 1016-1022.

Kak, A.C. and Slaney, M. (1988). Principles of Computerized Tomographic Imaging. IEEE, Inc., New York, IEEE Press.

Kockenberger, W. (2001). Functional imaging of plants by magnetic resonance experiments. Trends Plant Sci. 6: 286-292.

Kremer, J. R., Mastronarde, D. N. and McIntosh, J. R. (1996). Computer visualization of three-dimensional image data using IMOD. J. Struct. Biol. 116: 71-76.

Mastronarde, D. N. (1997). Dual-axis tomography: an approach with alignment methods that preserve resolution. J. Struct. Biol. 120: 343-352.

McIntosh, J. R. (2001). Electron Microscopy of Cells: A New Beginning for a New Century. J. Cell Biol. 153: 25F-32F.

Medalia, O., Weber, I., Frangakis, A. S., Nicastro, D., Gerisch, G. and Baumeister, W. (2002). Macromolecular Architecture in Eukaryotic Cells Visualized by Cryoelectron Tomography. Science 298: 1209-1213.

峰雪芳宣、唐原一郎 (2004) 細胞・オルガネラレベルでの電子線トモグラフィー．顕微鏡 39: 15-17. 峰雪芳宣、唐原一郎、村田隆、Otegui, M.、Giddings, T.H.Jr.、Staehelin, L.A. (2001) 植物組織の 高圧（加圧）凍結. 電子顕微鏡 36: 105-107.

峰雪芳宣、村田隆、Giddings, T.H.Jr.、Staehelin, L.A. （1998） 加圧凍結法による高等植物実生 分裂組織細胞の観察. Plant Morphology 10:30-39.

村田長芳、菅沼龍夫、峰雪芳宣（2000） 固定法 3. 高圧凍結. 電子顕微鏡 35: 109-110. 
Murata, T., Karahara, I., Kozuka, T., Giddings, T. H., Staehelin, L. A. and Mineyuki, Y. (2002). Improved method for visualizing coated pits, microfilaments, and microtubules in cryofixed and freeze-substituted plant cells. J. Electron Microsc. 51: 133-136.

Radon, J. (1917). Uber die Bestimmung von Funktionen durch ihre Integralwarte laengs gewisser Mannigfaltigkeiten. Ber. Saechs. Gesells. Wiss, Math.-Phys. Klasse 30: 262-277.

佐藤主税、上野豊、小椋俊彦、藤吉好則（2002） 単粒子解析法による結晶を用いない蛋白質構造 解析：電圧依存性 $\mathrm{Na}^{+}$チャンネルの構造を例として。電子顕微鏡 37: 40-44.

Stuppy, W. H., Maisano, J. A., Colbert, M. W., Rudall, P. J. and Rowe, T. B. (2003). Three-dimensional analysis of plant structure using high-resolution X-ray computed tomography. Trends Plant Sci. 8: 2-6.

田中信夫 (2004) 材料・デバイス系試料の電子線トモグラフィー． 顕微鏡 39: 26-30.

van Heel, M., Gowen, B., Matadeen, R., Orlova, E. V., Finn, R., Pape, T., Cohen, D., Stark, H., Schmidt, R., Schatz, M. and Patwardhan, A. (2000). Single-particle electron cryo-microscopy: towards atomic resolution. Quart. Rev. Biophys. 33: 307-369. 